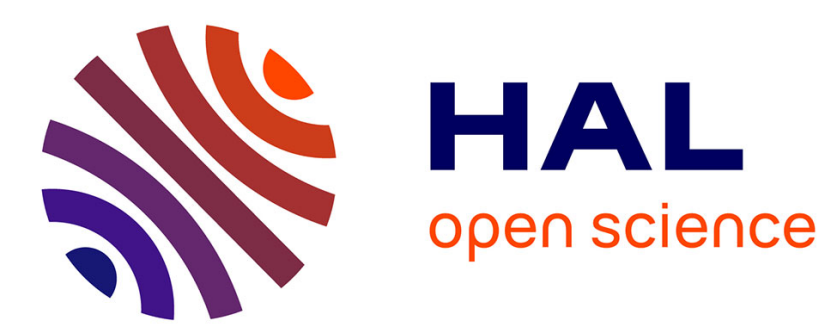

\title{
Governance, accountability and neighbourhood policing in Northern Ireland: analysing the role of public meetings
}

\author{
Mark Brunger
}

\section{- To cite this version:}

Mark Brunger. Governance, accountability and neighbourhood policing in Northern Ireland: analysing the role of public meetings. Crime, Law and Social Change, 2011, 55 (2-3), pp.105-120. 10.1007/s10611-011-9273-x . hal-00669192

\section{HAL Id: hal-00669192 \\ https://hal.science/hal-00669192}

Submitted on 12 Feb 2012

HAL is a multi-disciplinary open access archive for the deposit and dissemination of scientific research documents, whether they are published or not. The documents may come from teaching and research institutions in France or abroad, or from public or private research centers.
L'archive ouverte pluridisciplinaire HAL, est destinée au dépôt et à la diffusion de documents scientifiques de niveau recherche, publiés ou non, émanant des établissements d'enseignement et de recherche français ou étrangers, des laboratoires publics ou privés. 


\title{
Governance, Accountability and Neighbourhood Policing in Northern Ireland:
}

\author{
Analysing the Role of Public Meetings
}

\author{
Mark Brunger*
}

\begin{abstract}
In Northern Ireland's move from conflict to peace, policing has remained close to the top of the political agenda. As part of the peace process, the Independent Commission on Policing (ICP) reported in 1999, and since its publication policing structures in Northern Ireland have undergone considerable reform. One of the threads of the ICP was to introduce a more nodal or networked approach to the delivery of policing that included the establishment of partnership policing structures. Against this backdrop, this article evaluates the use of the recently established Partners and Communities Together (PACT) public meetings in their role as a tool in re-shaping the parameters police accountability in Northern Ireland. The model explicitly promotes a more nodal approach to local police decision making by engaging with a more diverse range of groups and harnessing the knowledge of local agencies to solve crime and disorder problems, and, therefore, enhancing the accountability and legitimacy of the PSNI at the local level. In these contexts, the article utilises data taken from fieldwork undertaken at these public meetings and critically considers their role as forums where communities bring low level disorder issues that are affecting their neighbourhood to the attention of the PSNI, and whether they help solve these issues in partnership. The article therefore offers an examination of the role of public meetings and the PACT model itself.
\end{abstract}

\section{Introduction}

There is no denying the significance of policing in Northern Ireland [6, 29]. As Northern Ireland has moved from conflict to peace, policing has remained close to the top of the political agenda. It is against this backdrop of debate and contention that this article sets out with the aims of evaluating the use of public meetings as a mode of police/public liaison, and subsequently as a tool in re-shaping the parameters of police governance and accountability in Northern Ireland, which has long been controversial. In these contexts, the article utilises 
data taken from fieldwork undertaken at Partners and Communities Together (PACT) public meetings. ${ }^{1}$

PACT is an embryonic form of police/citizen liaison. Influenced by North American communitarian thinking of the last two decades, it places emphasis on bringing partnership working into the governance of public service delivery. In Northern Ireland, it provides a fixed point of contact between the Neighbourhood Policing Teams (NPTs) of the Police Service of Northern Ireland (PSNI) and the public. In this sense, PACT represents the new beginning to the governance of policing in Northern Ireland and how public policing in particular is more accountable to the public. PACT thereby follows the spirit of the Independent Commission on Policing (ICP), which recommended that,

Below district level, local communities and police should be encouraged to develop consultative forums on lines that suit them and their neighbourhood. We recommend that it should be the aim of every police beat manger to have such a forum in his or her patrol area. [19: 35]

In this context, then, the PACT model provides an example of efforts by the PSNI to embed the pivotal recommendation 44, 'policing with the community' of the ICP [19; 40-45], and in doing so, promote a more nodal approach to local police decision-making by engaging with a more diverse range of groups and harnessing the knowledge of local agencies to solve crime and disorder problems.

The discussion which follows will make three arguments in relation to these public meetings. First is that PACT public meetings provide forums for the public to bring low level disorder issues to the attention of the PSNI, who, in turn, help solve these issues in partnership with them. Second, however, the argument is made that due to low attendances,

\footnotetext{
*Lecturer in Policing at Canterbury Christ Church University and currently completing his PhD at Queen's University Belfast.

${ }^{1}$ The article is a modification of a chapter in the unpublished $\mathrm{PhD}$ thesis of the author. The data utilised in the following analysis is drawn from field notes taken from detailed observations of interactions between the police and the public at PACT public meetings prior to, and proceeding these meetings. This fieldwork was undertaken at two PACT partnerships in Northern Ireland.
} 
the public meetings are unrepresentative of the local community. This leads to the final assessment that PACT partnerships have not made any real impact in changing the way local policing is governed or to working practices themselves. The main contribution of PACT lies in its symbolic role of fostering greater community involvement, particularly through using public meetings, rather than actually delivering it. This symbolic role is further amplified and consolidated through the meanings and representative practices that take place within the operation of the public meetings. The final part of the article uses an empirical example of a PSNI presentation at a public meeting, to illustrate that public meetings provide PSNI officers an arena where they can engage in dramaturgical performances, from which their message can be conveyed to the assembled audiences. ${ }^{2}$ To begin with, however, it is appropriate to provide an understanding of the overall structure of the PACT model in Northern Ireland.

\section{The Structure of PACT partnerships}

In Northern Ireland, PACT is organised in district council wards, where each partnership provides a single point of contact between the PSNI and the public within each respective ward. ${ }^{3}$ The official PACT guidance documents $[34,37]^{4}$ that are disseminated to PSNI officers identify the PACT model as the 'minimum expected standard means of community engagement' for the PSNI. In this sense, PACT is promoted as 'neighbourhood focused' and 'neighbourhood owned'[37; 1], and as providing a mechanism that 'give[s] focus for identifying community concerns', thus 'encouraging communities and neighbourhoods to identify and solve problems alongside the PSNI' [36; 12]. PSNI engagement with PACT is

\footnotetext{
${ }^{2}$ This data analysis draws on the work of Hall [9], in particular the metaphorical concepts of encoding and decoding of preferred readings.

${ }^{3}$ It is worthy of note that during the period of this research, PACT partnerships are now well established in many council wards in Belfast, but, although they are increasing, they remain sporadic outside Belfast's city boundaries.

${ }^{4}$ Both documents are non-confidential internal PSNI training documents that are widely disseminated to PSNI neighbourhood policing teams and are available on the internet. In this case they were provided to me by a respondent to the research.
} 
undertaken by the PSNI Neighbourhood Policing Teams (NPTs) [37; 1]. NPTs were established within the PSNI in April 2003, ${ }^{5}$ also as a direct response to the ICP recommendation "that neighbourhood policing teams be empowered to determine their own local priorities and set their own objectives, within the overall annual policing plan and in consultation with community representatives" [19; 44]. Recommendation 7 of the 25 Neighbourhood Policing Recommendations, set out by the Northern Ireland Policing Board, states that "each defined geographic neighbourhood must have a dedicated and identifiable officer or team of officers allocated ownership and responsibility for that defined geographic neighbourhood" [34].

NPTs, then, have been tasked with setting up PACT in their respective locales, with their official role being "to deliver effective community engagement by gaining an understanding of the communities priorities and what the residents feel are the most important issues to improve their neighbourhood" [36; 3]. Indeed, Recommendation 18 of the 25 Neighbourhood Policing Recommendations states, "a neighbourhood consultative forum, in keeping with the PACT model, should be established within each neighbourhood. Existing community engagement should be reviewed to establish if they meet the needs of each defined geographic neighbourhood."

The PACT partnership model involves PACT public meetings and PACT panels [37; 1]. These take place together at two monthly intervals. As the guidance notes propose, the public meeting format provides NPT officers the 'opportunity to communicate with local people' and 'enable low level, localised policing issues to be addressed together, through partnership with communities' [36: 2]. PACT public meetings are based upon an 'open'

\footnotetext{
${ }^{5}$ As a primary engagement tool, the idea of NPTs is founded in the idea of 'team policing', first developed in Los Angeles, in the 1970s, under the police chief Edward Davis. See Harrison-Moore [10] and Herbert [11]. They were rolled out under the auspices of the Neighbourhood Policing Programme (2006-08) as part of the Labour governments policing reform programme. The Home Office [16] committed itself to ensuring every 'community would have a NPT' by 2008.
} 
format, which places emphasis on encouraging public discussion, where the agenda is directed by the audience. ${ }^{6}$ Any issues raised are then prioritised and taken forward to the PACT panel, which assembles after the public meeting. The PACT panel is made up of members of the local NPT, a mix of local community representatives, representatives of statutory agencies with offices in the neighbourhood, and local politicians. The field work documented that agencies and organisations such as the women's refuge, restorative justice organisations, the local housing executive and local council representatives, such as the roads service, and local politicians were all brought together within PACT in Northern Ireland.

The role designated for the panel is to 'allocate tasks and actions arising out of the identified priorities' [37: 1]. On this basis, it is up to the panel members to decide upon how, based upon the efficacy, reasonableness and operational viability, the issues proposed should be prioritised by the NPT or other agencies if so required. ${ }^{7}$ The PACT guidance makes clear that "the role of partners on the PACT panel is not to make decisions on behalf of their organisations but rather to ensure that the right person takes the right action" [36: 2, emphasis added]. The underpinning premise of PACT is that it should not be seen as 'police initiatives' [36: 5]. Figure 1 illustrates the PACT process.

\footnotetext{
${ }^{6}$ It is noteworthy that the PACT public meeting is structurally close to the beat-fora style of public meeting popular in the United Sates where members of local neighbourhoods can offer their views unregulated on issues that concern them, direct to local police officers. Moreover, a recent resurgence of the idea in England and Wales where, along with the rollout of the PACT partnerships in some areas, a reinvigoration of public meetings, in the form of 'face-the-people' sessions, has taken place as a means of making Crime and Disorder Reduction Partnerships more accessible and accountable to the public. Furthermore, the public meeting is included, along with other participatory processes, in the Home Office's five primary engagement methods, which include surgeries, face-to-face surveys, environmental visual audits and post cards, as hallmarks for community engagement [15].

${ }^{7}$ As the guidelines state, 'joint action or be organisation specific' [37: 1].
} 


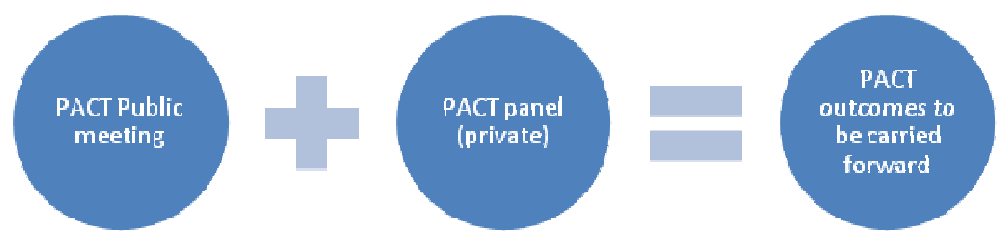

Figure 1: The PACT partnership process

The PACT public meetings visited by the author during fieldwork were held in community and church halls. In the spirit of the 'community ownership' ethos, public meetings are chaired by a member of the public [37: 1]. The role of the chair is to manage the meetings, encourage the participation of the audience and resolve any arising problems [36: 2].

However, in some of the meetings attended the chair was absent and a member of the NPT chaired the meeting instead, suggesting that while meetings may not be directly controlled by the PSNI, the PSNI presence is overarching within them.

\section{The development PACT in Northern Ireland}

The PACT model has antecedents that reach beyond Northern Ireland. The origins of the concept of PACT can be traced back to attempts to re-invigorate community activism in the United States during the mid-1990s, particularly during Bill Clinton's presidential administration (1992-2000). The community activist agenda was closely connected to the writings of Putnam [38-40] and other communitarians [7] who argued that the 1970s and 1980s had been characterised by a marked decline in civic participation in the US, particularly in the membership of civic organisations, voting participation and political activism [40]. Furthermore, Putnam argued that changes in family structures, such as more people living alone, the increase in suburban sprawl and the increasing availability of cheap 
electronic home entertainment were contributing factors to a marked decline in civic participation; the main building block of strong social capital amongst communities [39-40]. He further argued [38: 113] that it was only through the invigoration and enhancement of social capital within communities, and encouraging them to participate in civic life that, what Etzioni called 'community spirit' could be invigorated [7: ix].

With the communitarian agenda in mind, the PACT model, with its strong partnership ideal, offers a tool to invigorate locally based participative democracy and encourage civic participation by increasing opportunities for citizens to engage in social networks, as encouraged by Putnam $[38,40]$. In this sense, the questions raised by Putnam and other communitarian thinkers have gone a some way in influencing the appeal of PACT and its growth in the United Kingdom ${ }^{8}$ amidst the recent Labour government's (1997-2010) conversion to the moral authoritarian communitarian ideal. ${ }^{9}$ However, it only tells part of the story as to how PACT has come to provide a police/public liaison mechanism within the neighbourhoods of Northern Ireland.

There was broad agreement amongst the senior PSNI commanders interviewed during the research that the main thinking behind the introduction of the PACT to Northern Ireland, and the subsequent active promotion of the model by PSNI Headquarters, lies with the PSNI's commitment to a community-policing model, as set out in recommendation 44 of the ICP on 'Policing with the Community' [19: 40-45] as well as the ICP's recommendations to have a community liaison mechanism in each area [19: 44]. PACT, therefore, holds a great deal of symbolic capital for the PSNI, providing a visible example that the PSNI are engaging and listening to the community. Moreover, the foregrounding of PACT also illustrates how

\footnotetext{
${ }^{8}$ On this growth see, http://www.westmercia.police.uk/pact/. http://www.lancashire.police.uk/neighbourhood. http://www.alvechurch-village-society.org.uk/pact.htm [35], Hope [16] and Hughes [17-18].

${ }^{9}$ Indeed, the PACT partnership model sits nicely with the communitarian based 'no rights without responsibility' discourse, which pervaded New Labour's 'Respect Agenda' [14].
} 
the PSNI are addressing the 'bread and butter' challenges of routine crime, rather than a counter-insurgency role. From discussions undertaken with senior PSNI officers it was made clear that support for PACT within the upper echelons of the PSNI is definitely influenced by this thinking. As one PSNI area commander stated:

The introduction of PACT in the Belfast wards is fully coherent with a policing environment that is guided by the ICP. (PSNI Area Commander, May 2009)

PACT partnerships also have another more practical appeal for PSNI area commanders in that they provide a tool that can be utilised to respond to the pressure placed upon them to achieve performance targets. The following extracts provide an overall flavour of the PSNI attitudes towards the PACT partnerships:

They (PACT partnerships) are very welcome, they are helping us (the PSNI) to communicate with local people and keep them informed with what we are doing in their locality. If I am honest, I place a lot of importance on the PACT initiatives. (PSNI Officer, November 2009)

The PACT partnership model? It's great, particularly the public meetings, they allow us (the PSNI) to assure, inform, consult the public on issues regarding to crime in their areas. (PSNI Area Commander, September 2008)

If I am honest, I would place them (PACT) as far more important than other partnerships, so yes, I place a lot of importance on the PACT initiatives. (PSNI Area Commander, September 2008)

In a similar light, evidence from conversations that were recorded during the fieldwork suggests that the model also receives enthusiastic support from other participants. The following extracts, taken from the field notes give substance to the point:

They (PACT partnerships) certainly allow for our community reps to meet the police officers who can best serve their needs on a regular basis. (PACT Chair, November 2009)

I think, to put it simply, PACT provides an example of a local, community-led partnership that is addressing community problems and delivering mutually agreed programmes of intervention. (PACT Panel Member, November 2009) 
PACT is helping scope out problems and priorities of the local communities...in the case of PACT in my constituency, it has certainly helped direct police response to neighbourhood concerns and provided a way of directing resources allocation decisions and ensuring that these are driven locally. (Belfast Councillor, May 2009)

PACT is an experiment. I can say for one thing, it is not about coming here and scoring points against the police. We are trying to build a genuine partnership... Our aim is to look at issues affecting the community and tackle them head on... We want to develop a real partnership... They are good. We have a base from which to build positive relationships between the police and the community... What we are doing here is providing effective neighbourhood focused action plans and locally based solutions to solve real issues. (PACT Chair, November 2009)

However, a modicum of dissent was also present:

PACTs are okay in theory, but I don't think they will work over here, we have too much going on already. We are still struggling to get DPPs [District Police Partnerships] right. They are just another good idea from England. (PSNI Area Commander, May 2009)

As regards to police and communities together, see, I keep getting the name wrong, yes, its partners not police. It may well be police as they are the only ones who bother to come. In addition, the community are just confused by the language that is used. They actually want visible, recognisable police officers to communicate with on a daily basis. PACT? Most of those in my community do not understand what it means. (Local Community Worker on PACT)

A number of factors then have driven the development of PACT partnerships in Northern Ireland. Primarily, however, and despite some dissent, the appeal of the model for the PSNI and other participants is that it provides a mechanism where a broader community-orientated, de-centralised and more accountable local policing can be fostered. PACT opens up the PSNI to public scrutiny and, thus provides a 'network' or hub for various organisations, agencies and citizens to come together and discuss crime prevention issues. This view is particularly salient in the context of Northern Ireland where there is a history of circumspection about the aims of public policing and debates surrounding the legitimacy of public policing $[6,19$ and 
30]. The following section explores a number of key issues that emerged from the fieldwork undertaken at PACT public meetings in the Belfast City Council area.

\section{Concerns and Limitations: Assessing PACT Public Meetings}

In one PACT public meeting attended during fieldwork a sparsely furnished church community hall was half-filled by about 20 members of the public. A large, white screen projected 'Welcome to Partners and Communities Together'. Proceedings began with the audience being invited to discuss their concerns about crime and disorder issues in the area. Each issue raised was placed on a board at the front of the hall and at the end of the meeting each attendee was invited to place a post-it note next to the issue that they wanted prioritised. Based upon this ranking, the audience was then informed which of the issues would be taken forward to the PACT panel. This formula is prescribed in the guidance documents [36] and one that was witnessed repeatedly by the author at PACT meetings. It was also a formula that was perceived as effective and successful in providing the community with a voice and ownership of the process.

However, PACT public meetings also provide a source of criminal intelligence gathering for the PSNI, as members of the public provide details of their concerns to those gathered. The police are highly dependent on information from the public in order to investigate crime successfully and so these meetings provide a valuable stream of information on crime which is then applied to the identification of 'problem areas'. In this respect, the PSNI are fully integrated into the National Intelligence Model and utilise a number of crime mapping technologies to augment this function. ${ }^{10}$ While perhaps seeming innocuous, there are some interesting implications at play here. For one, crime mapping enables law

\footnotetext{
${ }^{10}$ As previously mentioned police services in the UK, including the PSNI, cooperate within the context of NIM. For the PSNI "District command units must ensure that neighbourhood concerns and community intelligence area central component of their NIM process" [34: recommendation 21].
} 
enforcement agencies such as the police to identify neighbourhoods that require 'resources put in'. In other words, it orders the prioritising areas of high crime that require particular police attention. ${ }^{11}$ Manning provides an articulation of the concept:

Crime mapping is a family of techniques designed to gather information on the temporal, spatial and social aspects of crime (offenders, victims, and their social characteristics such as race, class, age and gender)... describe their patterning... and direct police resources in order to reduce the levels of crime shown. [28:4]

Crime mapping has allowed police services in the UK to assemble intelligence data from the different partners involved in crime reduction and to improve targeting and resource deployment [13]. This function is particularly salient given the influence of the National Intelligence Model which coordinates intelligence across the UK police services. In the language of crime mapping, areas are designated as 'hot spots', referring to visible clusters of high crime [28: 18]. If used appropriately crime mapping can assist in problem-solving, however, used erroneously it can produce police saturation and result in the displacement effect of pushing crime into other areas [26]. Further, the notion of hot spots can reduce crime to matters of technicality, with the reasons why the crime might occur or why crime might be clustered within certain areas ignored.

The PSNI have incorporated the 'hot spot' concept into their everyday language, and frequently utilise the term in their statistical presentations at PACT public meetings. The effect of highlighting 'hotspots' as risk-laden areas is that wards are consequently divided into geographical 'good' and 'bad' areas, based solely on the prevalence of crime; again without consideration of why crime might be high in those areas. ${ }^{12}$ These areas can become

\footnotetext{
${ }^{11}$ The technological side of crime mapping and subsequent analysis involves consulting a wide range of methods, including computerised software such as COMPSAT which was developed by the NYPD in 1995 but also more conventional means of policing such as liaising with elements of the public $[28,1]$.

${ }^{12}$ Indeed, in policing terms, such geographical specification of crime is not new. As Manning [28] for one has noted, geographical crime maps were first used in nineteenth century London and were more frequently utilised in Chicago form the 1920s. Moreover, in Northern Ireland, the RUC also utilised a mapping system to chart
} 
identified as geographical areas of risk to outsiders, and result in the labelling and stigmatisation of all those who reside in these neighbourhood as troublemakers [45].

\section{Assessing the outcomes of PACT public meetings}

Figures $2 \& 3$, drawn from published meeting minutes, provide an understanding of the types of issues raised at PACT public meetings.

areas of high concentrations of sectarian conflict: areas were designated, white, grey and red areas, with red being the most hostile areas for police presence. 


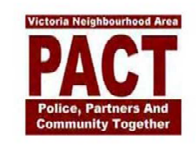

PANEL AGREED PRIORITIES

$29^{\text {th }}$ September 2009 at $8.00 \mathrm{pm}$ in Heyn Hall, St Mark's Church, Holywood Road, Belfast

\begin{tabular}{|c|c|c|c|c|c|}
\hline Priority & Action & Name & Timescale & Resources & Progress \\
\hline $\begin{array}{l}1 \\
\text { Damage to } \\
\text { wooden door at } \\
\text { electricity sub } \\
\text { station at } \\
\text { Belmont } \\
\text { Presbyterian } \\
\text { Chruch, } \\
\text { Sydenham } \\
\text { Avenue. }\end{array}$ & $\begin{array}{l}\text { Police to refer to } \\
\text { NIE } \\
\text { Police to carry out } \\
\text { patrols \& include } \\
\text { in anti-social } \\
\text { behaviour } \\
\text { operations. }\end{array}$ & Constable Boyd & 2 Weeks & $\begin{array}{l}\text { Victoria } \\
\text { Neighbourhood } \\
\text { Policing Team. }\end{array}$ & \\
\hline $\begin{array}{l}2 \\
\text { Damage to gate } \\
\text { - not reported to } \\
\text { police at known } \\
\text { number in } \\
\text { Holywood Road. }\end{array}$ & $\begin{array}{l}\text { Police to speak to } \\
\text { owner of property } \\
\text { and investigate as } \\
\text { necessary. Area } \\
\text { to be included in } \\
\text { NPT anti-social } \\
\text { behaviour ops. }\end{array}$ & Constable Boyd & By next meeting & $\begin{array}{l}\text { Local } \\
\text { Neighbourhood } \\
\text { Officer }\end{array}$ & \\
\hline $\begin{array}{l}\text { School children } \\
\text { smoking at }\end{array}$ & $\begin{array}{l}\text { NPT officer to } \\
\text { check the location } \\
\text { for this, and }\end{array}$ & Constable Boyd & By next meeting & $\begin{array}{l}\text { Local } \\
\text { Neighbourhood } \\
\text { Officer } \\
\end{array}$ & \\
\hline
\end{tabular}

Figure 2: Published minutes from a Belfast based PACT meeting (Sep, 2009) 


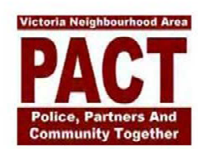

PANEL AGREED PRIORITIES

$29^{\text {th }}$ September 2009 at $8.00 \mathrm{pm}$ in Heyn Hall, St Mark's Church, Holywood Road, Belfast

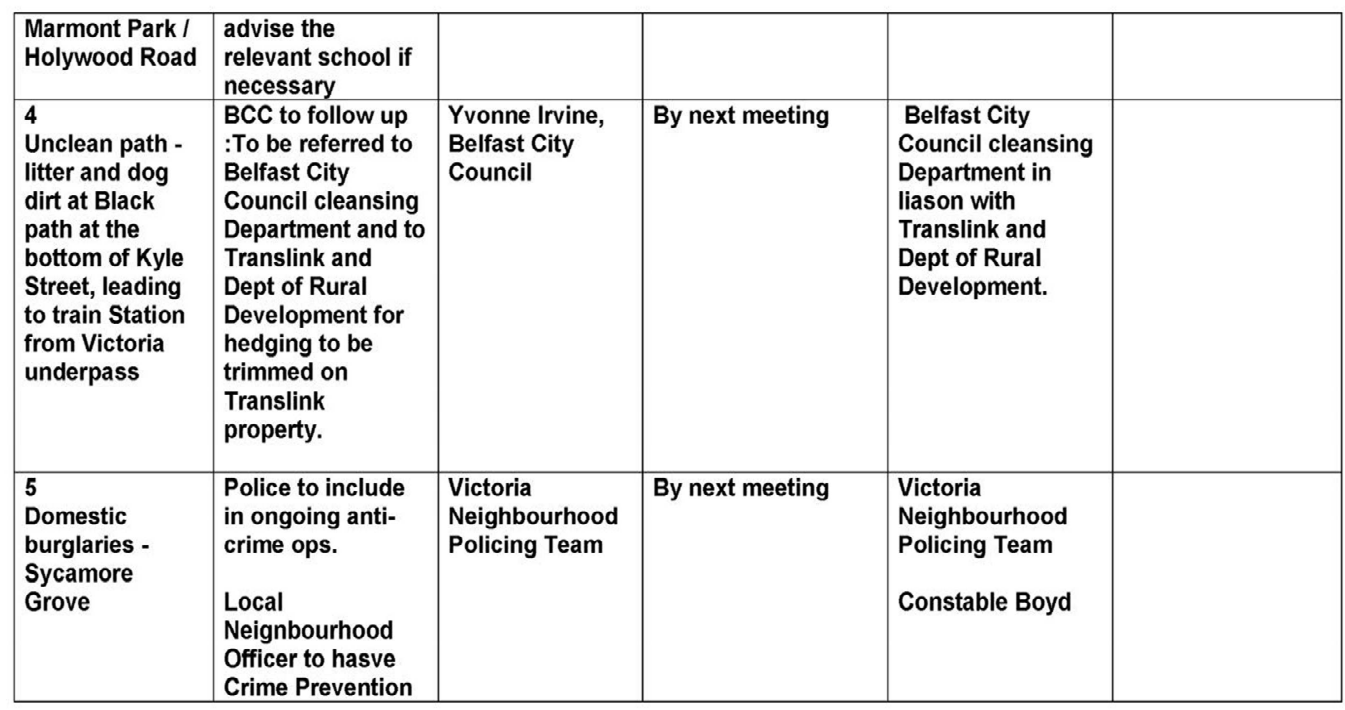

Figure 3: Published minutes from a Belfast based PACT meeting (Sep, 2009)

As well as providing a window into the meetings, these visuals direct us to some interesting points of discussion. In the first instance, the preoccupation with 'quality of life' and somewhat mundane issues is striking. Apart from the issue of domestic burglary, which is identified at point 5 in figure 3, the main issues involve damage to a substation door, damage to a gate, school children smoking and dog fouling. Specific attention will now be paid to the issue of 'school children smoking' and what this example alerts us to with regard to matters concerning local neighbourhoods. 
This example suggests what behaviour those attending public meetings perceive as important in respect of the profile of the neighbourhood. Innes' work on 'signal crimes' [2022] provides an important point of reference here. Signal crimes are those activities which indicate or 'signal' to a community that they are at risk. Innes explains how people's perceptions of what constitutes crime and disorder within their neighbourhood shape their broader view of how well the police are performing their functions. Innes also contends that this helps explain how in some areas higher levels of disorder are tolerated, but in other areas low levels of disorder or isolated incidents are out of character and are seen as intolerable [2].

Therefore, PACT partnerships are well placed to identify 'signal' issues in particular areas, and offer solutions to some local issues, particularly for those who partake in the public meetings (see below). In this sense, PACT public meetings provide a forum or outlet whereby the public can identify the local issues affecting their feelings of safety in their daily lives and provide the PSNI a forum at which solutions can be implemented and people can be reassured.

That said, the above example also illustrates that the PSNI are often placed in the position of offering 'security solutions' to these minor problems of disorder, which in any other circumstances might otherwise be dealt with by other organisations. Striking in figures 2 and 3 is the fact that the PSNI provide the majority of solutions, not any of the other partners, effectively making them the main power broker in the process. It raises the question, therefore, as to whether partnership policing is really being extended across local communities or just extending public policing into 'owning' more issues. It is a problem is highlighted by a PSNI area commander:

You know, when the council haven't fixed the street lighting or cut back the hedgerows or the housing association have not boarded up empty houses it us they call. (PSNI Area Commander, September 2009) 
Also, PACT public meetings are the only regular public forums that take place on such a micro-local level. If the police dominate these meetings then solutions formulated through the lens of security are an inevitable consequence.

As I said before, the PSNI are the only ones who come to the meetings on a regular basis. But, others only seem to come to meetings when it suits them. Thus, it is only the PSNI who appear keen to get involved in solving our problems. (Belfast Councillor, May 2009)

Overall then, what is discernable so far in this analysis is that PACT public meetings might be providing a sense of what the social ills of the neighbourhood are, but the prominent role of the police means that outcomes might further consolidate security and crime prevention as central 'catch all' concepts from which all nature of problems can be viewed and potentially solved.

\section{Representativeness of Public meetings}

A concern with PACT public meetings was that participation at them was found to be invariably unreflective of the demographics of the respective council wards where they took place. By contrast, audiences were only representative of a small fraction of local populations. As well as being low in number, they were skewed in terms of age and class, with public meetings often made up of well-dressed males, over the age of $50 .{ }^{13}$ This raises a number of concerns. Firstly, can accountability to the 'community' be claimed if the issues that arose at public meetings are only the concerns of the few who attend? Secondly, if attendance only reflects an active few, then PACT public meetings may only be serving to represent parochial rather than broader interests. In other words, they only offer a barometer of intolerance within these neighbourhoods of perceived unsavoury acts, rather than

\footnotetext{
${ }^{13}$ Similar results have been found in other societies by Skogan [44] and Terpstra [45]. Skogan [44], the most prominent exponent of public/police liaison mechanisms in North America, consistently finds that participation in such mechanisms is consistently skewed towards middle class males.
} 
providing a general measure of criminal activity. Indeed, if the mood of some of the public meetings that were attended by the author are to be taken as a barometer of attitudes, one increasingly comes to the conclusion that there is a developing anger towards a select disruptive minority, who are accused of lacking 'responsibility' or 'respect' for their community [41].

No doubt, for those who do attend, the presence of the police in their neighbourhoods does provide a feeling of security in what Crawford \& Lister [4] have called 'bonding capital', where public meetings unite and 'bind together' those with similar interests and mindsets. However, while public meetings provide a sense of what the social ills and security issues are in particular neighbourhoods, questions need to be asked as to whether public meetings are representative of these concerns.

\section{Preventing Burglary in the Home}

A final critique of PACT public meetings can be made through a consideration of a PSNI presentation made at a public meeting attended during the fieldwork. The subject of the presentation centred on highlighting the threat of predatory burglars, and what steps the public could take to reduce the opportunities for such events. The following field note extract illustrates some of the examples that were given:

Lock your cat flaps. There are Fagin type characters that use children to do burglaries and who will crawl through the flaps... Do not place your name and address on your holiday baggage. These types are going to airports, reading your baggage labels and then going and robbing your house... Do not leave your 'sat-nav' holders in your car... Do not leave your car running, de-icing, whilst you go back in the house, as they will steal your car... Do not leave your keys near the front door; thieves are using fishing rods and coat hangers to fish them off key hooks... Do not allow postal worker to leave parcels in your garden. (Belfast PACT Public Meeting November 2009) (emphasis added) 
In trying to unravel the underpinning rationale of this presentation a number of inferences can be made. Firstly, the audience are expected to believe the truth of what was being conveyed. The examples above were accompanied by a tightly managed and staged performance, which seemed to be aimed at conveying particular meanings to the audience. But, these meanings are derived, in part, from how the audience decode what they are being told [27: 28]. The inference here is that audiences develop complex beliefs about crime from direct and indirect images, which play an important role in shaping how they react to future events and acts, even if they have no direct experience of them [43]. In this case no supporting evidence was given to substantiate any of the examples given, nor was any attempt made to educate the audience about the underlying causes of crime or why it might happen.

Secondly, presentations such as these may be an attempt to re-responsibilise the citizenry into looking after themselves, and, therefore, be less reliant on the public police. But, the main point derived from the presentation, particularly from watching the faces and expressions of the other members of audience, was that by highlighting these representations of burglary the fear of crime in the audience appeared to be exacerbated. They looked shaken by the stories, which seemed to purvey a sense that falling victim to burglary or property theft is an everyday and regular occurrence for most people. Such fears about crime are not isolated. Indeed, $65 \%$ reported to the Northern Ireland Crime Survey that they believed levels of crime had risen in Northern Ireland between 2007 and 2008 [31].

By contrast, according to figures from the same survey, the risk of being a victim of crime has been consistently falling; a trend that is congruent with the rest of the UK. ${ }^{14}$ Moreover, the risk of being a victim of crime in Northern Ireland remains lower at $13.8 \%$

\footnotetext{
${ }^{14}$ If we compare British Crime Survey's data for 1995-2005, it illustrates that crime has halved in that period (see the Home Office Statistical Bulletin, 2005).
} 
than in England and Wales where it stands at 22.1\% [33]. Although caution must be exercised in the use of any statistical evidence regarding crime rates [12, 27: 290, 25 and $46]^{15}$, there is clearly a difference between the likelihood of victimisation and the fear of victimisation. That said, it is also the case that crime and victimisation is often concentrated in small neighbourhood areas which report higher levels of crime and victimisation than officially collected survey data [5]. This may, in many respects, provide some foundation for the PSNI to premise such a presentation.

However, the point here is that it is clear that the chances of becoming victim to an opportune thief or predatory burglar, such as in the examples given in the presentation, is subject to an array of complex variables, which were simply not conveyed in the presentation. PACT partnerships and NPTs should have an important role to play in reassuring nervous communities about local crime issues, rather than conveying information about the prevention of volume crimes. This presentation did not, however, present a key message of reassurance, but one that seeks to encode a picture of a grim and scary world, where burglary and theft are premised as pervasive and regular occurrences for everybody. This creates a sort of myth-making, where constructed images, narratives about crime and dominant assumptions around the imagery of criminality are enforced. On another level, imagery of criminal types are portrayed, situations and areas become identified as places of risk resulting in the labelling and stigmatisation of all those discussed, such as the young [45]. It also takes the mind of the receiver away from other, perhaps more pressing, local issues. ${ }^{16}$ If we reconsider figures 2 and 3, burglary did feature, but other, more mundane disorder related issues took preference. The concentration in highlighting the dangers of becoming a victim of

\footnotetext{
${ }^{15}$ Ellison \& Shirlow [5: 10] reported that $55.69 \%$ of crime went unreported in the inner city area of Belfast which they surveyed.

${ }^{16}$ Such contentions are also supported by evidence from recent NICS [31] data which reported that $68 \%$ of people living in areas with a high level of anti-social behaviour exhibit a low confidence in policing. Recent evidence also suggests that anti-social behaviour appears to be a significant contributor to the 'fear of crime' in urban areas [5 and 42].
} 
volume crime such as burglary work in a paradoxical manner, particularly through the possible effect of heightening the fear of crime through the dramatisation of the experiences of crime by elaborating extreme case studies.

However, with the PSNI facing a pervasive performance target regime, the presentation might be a means of prioritising in the minds of the audience key performance targets such as reducing burglary. It gives little consideration though to how audiences decode such presentations. On the other hand, these presentations also provide an opportunity to emphasise the pressing need for the reduction of such crimes. ${ }^{17}$ But the problem here is that by asserting measurable volume crimes they shift the emphasis away from 'local solutions to local problems.' [8]

Overall, the scenarios presented in the example given above can be regarded in what Manning termed, 'expressive communication'; where situations are made significant and meaningful in order to convince audiences of its truthfulness [27: 23-24]. As Manning argues, the police often see themselves in an advisory role to the public, co-opting friendly elements into fighting crime with them and establishing the symbolic rationale of "crime fighting' [27: 326].

\section{Conclusion}

PACT public meetings offer the PSNI a forum for direct face-to-face interaction with the public and other local groups to discuss local crime and disorder issues. The idea is to promote a plural approach to police decision-making that is situated in a clear attempt to shift the emphasis away from conflict related priorities, broaden engagement with policing in local

\footnotetext{
${ }^{17}$ It is noteworthy that since the research was concluded the PSNI was responding to the issue of anti-social behaviour, as illustrated in its rising in prominence within the key community safety and policing targets. For instance, the PSNI have a target of reducing incidents of anti-social behaviour by 5\% in the 2007-2010 policing plan. Moreover, anti-social behaviour is now a priority in the Public Service Agreement targets for 2008-11, which seeks a reduction of anti-social behaviour by $15 \%$ over this period [32].
} 
neighbourhoods and extend police accountability to the community. In this respect, throughout the research for this article, the general feeling that was conveyed from the PACT public meetings was that this type of police/public engagement is fully commensurate with the vision and spirit of the ICP [19].

Based upon the evidence presented here, the support for the PACT partnership model emanating from the upper echelons of the PSNI does play an important symbolic tool to legitimate change in policing. But the meetings appear to be nothing more substantial than either a managerial innovation to guide the work of NPTs or a crime-mapping tool to gather information on local crime. The systems are constrained by the overarching presence of the guidance documents, and, therefore, these public meetings are perhaps having little impact on the everyday practices of the PSNI.

The article also illustrated that the public meetings provide a forum whereby the public can identify and communicate to the PSNI low level disorder or 'signal crimes'. In this sense, the meetings have the potential to act as a space where information and knowledge is exchanged and reassurance can be provided by NPTs. Through consideration of the published minutes of a PACT panel it was noted how many of the issues that are brought up at public meetings are rather prosaic and hard to measure issues. The problem highlighted here, however, is that the PSNI are often brought in to deal with issues that could, and possibly should, be dealt with by other authorities. In addition, poor attendances at PACT public meetings meant that the problems brought to public meetings cannot be considered broadly representative of local neighbourhoods. Therefore, it is insufficient to rely on public meetings alone to act as a barometer of consent for police action within these locales. Despite these problems, public meetings are not redundant; rather they should be used along with other 
methods to ensure the PSNI canvass the wider community for their views in an as inclusive a manner as possible. ${ }^{18}$

Finally, the article also provides an example of how a PACT public meeting was used to encode a preferred reading by the PSNI in the importance of reducing domestic burglary, and the role the public can play in its reduction. In this sense, encoding of preferred messages was undertaken through a PSNI presentation, which, it was argued, involved a dramaturgical performance. The point of this example was to illustrate the potential that public meetings provide for the police to make impressions on audiences and utilise their expertise in security to prioritise key crimes, in this case domestic burglaries. The argument was also made however, that despite what was intended this process produces a paradoxical problem, whereby the presentation also exacerbated the audiences' anxiety about the fear of crime and perhaps affirmed common assumptions about the nature of criminality.

Much of what has been reported here has some parallels with other work that has been researched in other jurisdictions [24, 25, 43, 44 and 46]. Unfortunately, it appears the case that PACT initiatives as a whole, do exhibit some of the same shortcomings that were reported in these studies, particularly the fact that PACT, like other partnership policing and crime preventative initiatives is a supplemental activity for the police. Nonetheless, it should be added, that despite the concerns reported here, some senior PSNI officers, as well as some politicians that were interviewed see the PACT model as both essential and beneficial to policing in Northern Ireland. They claim the fact that as such meetings are 'open' to all is enough to establish them as an accountability mechanism for local police operations as well as providing a valuable addition to the provision of more democratic governance of policing. In drawing a final conclusion, the PACT partnership model remains in a developmental stage

\footnotetext{
${ }^{18}$ One might consider, for example, community TV networks, particularly in health centres, public buildings and even in supermarkets and petrol stations to advertise and encourage engagement [3].
} 
in Northern Ireland, and in these early days one has to be cautious of pigeon holing PACT in the 'nothing works' category. 


\section{Reference List}

1. Audit Commission. (2006). Neighbourhood Crime and Anti-Social Behaviour: Making Places Safer through Improved Local Working. Community Safety National Report, May 2006, Milbank, London.

2. Barnes, E., \& Eagle, T. (2007). The Role of Community Engagement in Neighborhood Policing. Policing, 1(2), 161-172.

3. Chess, C., \& Purcell, K. (1999). Public Participation and the Environment: Do we know what works? Environmental Science \& Technology,33(16), 2688-2690.

4. Crawford, A., \& Lister, S. (2006). Additional Security Patrols in Residential Areas: Notes form the Marketplace. Policing and Society, 16(2),164-188.

5. Ellison, G., \& Shirlow, P. (2008). Community Attitudes to Crime, Anti-Social Behaviour and Policing in the Greater New Lodge. Institute of Criminology and Criminal Justice, School of Law, Queen's University Belfast.

6. Ellison, G., \& Smyth, G. (2000). The Crowned Harp: Policing Northern Ireland. London: Pluto Press.

7. Etzioni, A. (1995). The Spirit of Community. London, Fontana.

8. Gilling, D, (2007). Crime Reduction and Community Safety: Labour and the Politics of Local Crime. Cullompton, Willan Publishing.

9. Hall, S. (1980). Encoding/De-Coding. In Hall, S. (Ed). Culture, Media \& Language. London, Hutchinson.

10. Harrison-Moore, M. (1992). Problem-Solving Community Policing. Crime \& Justice, $15,99-157$.

11. Herbert, S. (2005). Citizens, Cops, and Power: Recognising the Limits of Community. Chicago, Chicago University Press.

12. Hillyard, P., \& Gordon, H. (1999). Arresting Statistics: The Drift to Informal Justice in England and Wales. Journal of Law and Society, 26(4), 502-522. 
13. Home Office. (2005). Crime Mapping: Improving Performances-A Good Practice Guide for Front Line Officers . Home Office, London.

14. Home Office. (2006). Respect Action Plan. London, HMSO. Available at http://www.respect.gov.uk/uploadedFiles/Members_site/Articles/About_Respect/resp ect_action_plan.pdf Accessed on 09 December 2010.

15. Home Office. (2007). Delivering Safer Communities: A Guide to Effective Partnership Working. Police Crime and Standards Directorate, London, HMSO.

16. Hope, T. (2005). The New Local Governance of Community Safety in England and Wales. Canadian Journal of Criminal Justice and Criminology, 47(2), 369-388.

17. Hughes, G. (1996). Communitarianism and Law and Order. Critical Social Policy, 16 (4) $17-41$.

18. Hughes, G. (2008). The Politics of Crime and Community. Palgrave MacMillan.

19. Independent Commission on Policing. (1999). Report of the Independent Commission on Policing in Northern Ireland A New Beginning: Policing in Northern Ireland. The Patten Commission Report, Belfast/London, NIO: HMSO.

20. Innes, M. (2004). Reinventing tradition? Reassurance, Neighbourhood Security and Policing. Criminal Justice, 4(2), 151-71.

21. Innes, M. (2004). Signal Crimes and Signal Disorders: Notes on Deviance as Communicative Action. British Journal of Sociology, 55(3), 335-55. Reprinted in Moss, K. (Ed.). (2008). Crime Reduction: Critical Concepts in Criminology, The Major Works. London, Routledge.

22. Innes, M. (2005). What's Your Problem: Signal Crimes and Citizen-Focused Problem-Solving (Reaction Essay). Criminology and Public Policy, 4(2), 187 - 200.

23. Kinsey, R. (1984). First Report of the Merseyside Crime Survey. Liverpool, Merseyside County Council. 
24. Maguire, M. (2002). Crime Statistics: The Data Explosion and its Implications. In Maguire, M., Morgan, R., \& Reiner, R. (Eds). The Handbook of Criminology. 3rd Edition, Oxford: Oxford University Press.

25. Morgan, R., \& Maggs, C. (1985). Setting the PACE: Police Community Consultation Arrangements in England \& Wales. Bath, University of Bath, Centre for the Analysis of Social Policy.

26. Maher, L., \& Dixon, D. (1999). Policing and Public Health: Law Enforcement and Harm Minimumisation in a Street-Level Drug Market. British Journal of Criminology, 39 (4), 488-512.

27. Manning, P. K. (1977). Police Work. Long Grove, Waveland.

28. Manning, P. K. (2008). The Technology of Policing: Crime Mapping, Information Technology, and the Rationality of Crime Control. New York University Press.

29. Morgan, R., \& Maggs, C. (1985). Setting the PACE: Police Community Consultation Arrangements in England \& Wales. Bath, University of Bath, Centre for the Analysis of Social Policy.

30. Mulcahy, A. (2006). Policing Northern Ireland: Conflict, Legitimacy and Reform. Cullompton, Willan Publishing.

31. Northern Ireland Office. (2008). Perception of Crime: Findings from the 2007/08 Northern Ireland Crime Survey. Northern Ireland Office/Northern Ireland Statistic Research Agency.

32. Northern Ireland Office. (2008). Together, Safer, Stronger: Community Safety in Northern Ireland: A Consultation Paper. Northern Ireland Office/Community Safety Unit, October 2008.

33. Northern Ireland Office. (2009). Experiences of Crime: Findings from the 2007/08 Northern Ireland Crime Survey. Northern Ireland Office/Northern Ireland Statistic Research Agency. 
34. Northern Ireland Policing Board. (2008). Neighbourhood Policing Recommendations. Northern Ireland Policing Board, Belfast.

35. 'PACT - Agreeing Local Priorities' http://www.westmercia.police.uk/pact/

36. PSNI (2009). Police and Communities Together (PACT) 'How to Guide', PSNI internal memorandum.

37. PSNI, (2009). Police and Communities Together (PACT) 'PACT 60 second briefing', PSNI internal memorandum.

38. Putnam, R. D. (1993). Making Democracy Work, Civic Traditions in Modern Italy. Princeton, Princeton University Press.

39. Putnam, R. D. (1995). Bowling Alone: America's Declining Social Capital. The Journal of Democracy, 6(1), 65-78.

40. Putnam, R. D. (2000). Bowling Alone: The Collapse and Revival of American Community. New York: Simon \& Shuster.

41. Scraton, P. (2008). Power Conflict and Criminalisation. Routledge.

42. Shirlow, P. \& Pain, R. (2003). The Geographies and Politics of Fear. Capital \& Class, $80,15-26$.

43. Skogan, W. (1986). The Fear of Crime and its Behavorial Implications. In Ezzat, A. F. (Ed). From crime policy to Victim Policy: Reorienting the Justice System. London, Macmillan, 167 - 188.

44. Skogan, W. (2006). Police and Community in Chicago: A Tale of Three Cities. Oxford, Oxford University Press.

45. Terpstra, J. (2009). Citizen Involvement in Local Security Networks. Security Journal, 22, 156-169.

46. Uglow, S. (1988). Policing Liberal Society. Oxford, Oxford University Press.

47. Weitzer, R. (1995). Policing under Fire: Ethnic Conflict and Police Community Relations in Northern Ireland. Albany: SUNY Press. 